\title{
Kavram Karikatürlerinin Fen Eğitimi Dersi Akademik Başarısı Üzerindeki Etkisini Belirlemeye Yönelik Bir Meta-Analiz Çalışması
}

\author{
Identifying the Concept Cartoons' Effect on Academic Achievement in \\ Science Course: A Meta-Analysis Study \\ Gürol YOKUŞ*, Burak AYÇIÇEK** \\ • Geliş Tarihi: 15.07.2019 • Kabul Tarihi: 01.10.2019 • Çevrimiçi Yayın Tarihi: 10.10.2019
}

\begin{abstract}
$\ddot{O} \mathbf{z}$
Bu araştırmanın amacı, Türkiye'de 2007-2019 yılları arasında kavram karikatürlerinin Fen Eğitimi dersi akademik başarısı üzerindeki etkisini inceleyen deneysel çalışmaların meta-analizini yaparak genel etki büyüklüğünü hesaplamak ve bu etkinin çeşitli moderatörlere göre anlamlı farklılık gösterip göstermediğini belirlemektir. Araştırma kapsamında birbirinden bağımsız deneysel çalışmaların sonuçlarını birleştirmek için meta-analiz yöntemi kullanılmıştır. Elde edilen çalışmalardan deneysel veya yarı deneysel yöntemle yürütülmüş olan, Fen Eğitimi dersi kapsamında gerçekleştirilen ve dâhil edilme kriterlerini karşılayan 23 adet tekil araştırma meta-analiz açısından uygun bulunmuştur. Derlenen araştırmalar arasında heterojenlik bulunduğu için etki büyüklüğü rastgele etkiler modeline göre hesaplanmıştır. Araştırma kapsamında moderatör değişkenler olarak kavram karikatürlerinin kullanılma süresi, araştırmanın türü, araştırmanın yapıldığı coğrafi bölge ve sınıf düzeyi belirlenmiştir. Kavram karikatürlerinin merkezde yer aldığı öğrenme-öğretme süreçlerinin öğrencilerin akademik başarısı üzerinde etkili olduğu, çalışmaların ortalama etki büyüklügünün 0,867 olduğu, pozitif yönde ve geniş etki büyüklüğüne sahip olduğu belirlenmiştir. Ayrıca, kavram karikatürlerinin kullanılma süresi ( 8 haftadan fazla) ve sınıf düzeyi (7. ve 8 . sınıflarda) değişkenlerine göre anlamlı farklılık bulunmuştur.
\end{abstract}

Anahtar sözcükler: kavram karikatürleri, meta-analiz, fen eğitimi akademik başarısı

Atıf:

Yokuş, G. \& Ayçiçek, B. (2020). Kavram karikatürlerinin Fen Eğitimi Dersi akademik başarısı üzerindeki etkisini belirlemeye yönelik bir meta-analiz çalışması. Pamukkale Üniversitesi Ĕgitim Fakültesi Dergisi, 49, 223-246. doi: 10.9779/pauefd.592287.

\footnotetext{
* Dr., Sinop Üniversitesi, ORCID: 0000-0002-4849-5829, gurolyokus@gmail.com

** Dr., Milli Eğitim Bakanlığı, ORCID: 0000-0001-8950-2207, aycicekburak@gmail.com
} 


\begin{abstract}
In order to determine the effect of concept cartoons on students' academic achievements in science course, this study attempts to make a meta-analysis of experimental and quasi-experimental studies -which are conducted in Turkey between years of 2007 and 2019- and find out whether this effect differs depending on various moderators. Metaanalysis is used as research method for combining the results of independent experimental studies. After applying inclusion criteria, 23 individual studies at total -which are conducted in science course with experimental design- are found appropriate for meta-analysis. As there is found heterogeneity between studies, random effects model has been used for calculating effect size. Moderator variables include duration of concept cartoons, research type, geographical region and class level. It comes out that concept cartoons-based instruction processes have a significant effect on the students' academic success, the average effect size is 0.867 and it is positive. Also, there is observed a significant difference depending on the duration of using concept cartoons (more than 8 weeks) and class level (at $7^{\text {th }}$ and $8^{\text {th }}$ graders).
\end{abstract}

Keywords: concept cartoons, meta-analysis, academic achievement in science

\title{
Cited:
}

Yokuş, G. \& Ayçiçek, B. (2020). Identifying the concept cartoons' effect on academic achievement in Science Course: A meta-analysis study. Pamukkale Üniversitesi Eğitim Fakültesi Dergisi, 49, 223-246. doi: 10.9779/pauefd.592287. 


\section{Giriş}

Eğitimde öğrenci merkezli öğrenme yaklaşımlarının ön plana çıtığı 21. yüzyılda (Gürol, 2003), öğrencinin merkezde olduğu etkin katılımı kolaylaştıran görsel araçlardan biri kavram karikatürleridir (Balım, İnel ve Evrekli, 2008). Kavram karikatürleri soru sormaya teşvik etmek, tartışma ortamı oluşturmak ve bilimsel düşüncenin üretilmesini sağlamak için hazırlanmış karikatür şeklindeki çizimlerdir (Long ve Marson, 2003). Dabell'e (2004) göre ise kavramsal karikatürler, konuşmaların karikatürize biçimde öğrenene sunulduğu bilişsel çizimlerdir. Kavram karikatürlerinde kullanılan karakterler tartışılan konuyla ilgili farklı bakış açılarını temsil etmektedir (Naylor, Downing ve Keogh, 2001). Öte yandan, Şaşmaz-Ören (2009) kavram karikatürlerinin günlük hayatta karşılaşılan problemler ile bilimsel konuların tartışılmasına ve yorumlanmasına imkân veren bir strateji olduğunu belirtmektedir. Keogh, Naylor ve Wilson'a (1998) göre kavram karikatürleri şu özellikleri içermelidir:

•Her yaştan ve düzeyden öğrencinin ilgisini çekebilir nitelikte olmalıdır.

•Öğrencilerin mevcut bilimsel fikirleriyle günlük hayatları arasında bağlantı kurabilmeleri için, karikatürde kullanılan bilimsel fikirler öğrencilerin günlük hayatta karşılaşabilecekleri türden olmalıdır.

•Her bir alternatif düşüncenin öğrenciler için aynı zorlukta olması sağlanmalıdır.

•Bilimsel olması koşuluyla alternatif düşünceler üretilmelidir.

Kavram karikatürlerinin kullanıldığı sınıfta bütün görüşler farklı şekilde işlenir ve bu farklılık, oluşan tartışma ortamında öğrencilerin düşüncelerini ortaya çıkarır. Kavram karikatürlerinin öğretilecek konu ile ilgili görsel öğeler içermesi, öğrencilerin ilgi ve motivasyonlarını artırmakta ve sıkılmadan öğrenmelerine imkân vermektedir. Bunun yanında kavram karikatürleri, soyut bilimsel kavramların öğrenciler tarafından daha iyi anlaşılmasını kolaylaştırmakta ve derinlemesine öğrenme fırsatı sağlamaktadır (Kirisçioğlu ve Başdaş, 2007). Kavram karikatürleri ile ilgili yapılan yorumlar, bu tür karikatürlerin etkin bir öğrenme ortamının oluşturulmasını sağlayan bir yöntem olması noktasında birleşmektedir. Bu noktada, fikirlerin doğru ya da yanlış olması önemli değildir. Olası bir yanlış fikir kendisine ait değil, hakkında yorum yaptı̆̆ karikatürde yer alan karakterlere aittir (Kabapınar, 2005). Böylece fikirlerin rahatça ifade edildiği, demokratik bir sınıf ortamının oluşması sağlanır. Bu durum öğrenenlerin düşüncelerini açıklama konusunda kendilerine güven duymalarını sağlayarak kendi fikirlerini yapılandırmalarına, kendi bilişsel yapılarında değerlendirmelere ve yeniden düzenlemelere firsat tanımaktadır. Kavram karikatürleri, öğrencilere görsel ortamlarda kavram ve bilgileri sunarak günlük hayatta karşılaşılan olaylara ilişkin bilimsel bakış açılarını kazandırıp (Martinez, 2004), tartışma ortamı yaratmakta, öz eleştiri firsatı sunmakta, kavram yanılgılarını gidermekte, araştırma yapmayı sağlamakta ve derse motivasyonu artırmaktadır (Dabell, 2004). Kavram karikatürleri, bilgilerin sorgulandığı, cevapların sabitleştirilmediği, birden fazla çözüm yolunun olduğu, derinlemesine öğrenmenin amaçlandığ 1 bir ortam sağlamaktadır. Alan yazında özellikle öğrencinin hangi karikatürün doğruyu söylediğini bulmak için düşünmesi, araştırması, sorgulaması, eleştirel bir tutum takınması, öğrenciler arasında etkin bir tartışma ortamı oluşturduğu belirtilmektedir (Demir, 2008; Webb, Williams ve Meiring, 2008). Ayrıca öğrenme sürecinde yaşanan yanılgıların çizgi karakterlerle kişileştirilmesi ve 
böylece bu yanılgıların ortadan kaldırılması kavram karikatürleriyle gerçekleşmektedir (Saka, Akdeniz, Bayrak ve Asilsoy, 2006).

Alan yazında kavram karikatürleri ile ilgili ulusal düzeyde yapılan çalışmalara bakıldığında kavram karikatürlerinin; öğrencilerin derse olan ilgilerini artırdığı (Aydın, 2015; Erdoğan ve Özsevgeç, 2012; Kaptan ve İzgi, 2014; Oruç ve Teymuroglu, 2011); öğrenciye birçok açıdan yararlar sağladığı ve derslerde kullanılması gerektiği (İnel, Balım, Evrekli, 2009); öğrencilerin dersi daha iyi anlamalarını sağladığı (Taşlıdere, 2013); öğrencilerin sorgulayıcı öğrenme becerileri algılarının gelişimi konusunda yararlı olabileceği (Evrekli, Balım, 2010); öğrencilerin kavramsal anlama düzeyleri ile problem çözme beceri düzeylerini etkilediği (Balım, Çeliker, Türkoğuz, Evrekli ve Ekici, 2015); kavram yanılgılarını azalttığı ve öğrencilerin konuları daha iyi kavramasını sağladığı (Demirel ve Aslan, 2014; Atılğanlar, 2014); öğrencilerin akademik başarılarını olumlu yönde etkilediği (Akbaş ve Toros, 2016; Çelik ve Gündoğdu, 2016; Çetin, 2012; Gölgeli ve Saraçoğlu, 2010; Güler, Çakmak ve Kavak, 2013; Kaplan ve Öztürk, 2015; Köklükaya, Yıldırım ve Selvi, 2016; Ocak, Islak ve Ocak, 2015; Özyılmaz-Akamca, Ellez ve Hamurcu, 2009; Yılmaz, 2013; Yolcu, 2013), kavramsal değişimi sağlamaya yardımcı olduğu (Atasoy, Tekbıyık ve Gülay, 2013); kavramsal değişim metinlerine oranla alternatif kavramların giderilmesinde daha etkili olduğu (Arıkurt, 2014; Özmen vd., 2012) ve sorgulayıc1 öğrenme becerilerini arttırdığg (Gül, Köse ve Konu, 2014) sonuçlarına ulaşılmıştır. Ayrıca, kavram karikatürlerinin geleneksel veya sadece programa dayalı öğretime kıyasla daha etkili olduğu (Tokcan ve Alkan, 2013); sınıf yönetimini, sınıf içi tartışmanın organizasyonunu kolaylaştırdığı ve kavram yanılgılarını gidermede etkili olduğu (Kabapınar, 2005) sonuçlarına ulaşılmıştır.

$\mathrm{Bu}$ araştırmanın amacı, kavram karikatürlerinin öğrencilerin Fen Eğitimi dersi akademik başarılarına etkisini belirlemektir. 21. yüzyılda yeniliklere açık, sorgulayan ve problem çözme becerisine sahip, bilgiye ulaşma yollarını bilen ve özerklik kazanmış bireylerin yetiştirilmesinde kavram karikatürlerinin kullanımının önemli katkılar sağlayacağı düşünülmektedir. Gelişmiş ülkelerde daha yaygın olan kavram karikatürlerinin, Türkiye'de de yaygınlaşmasını sağlamak açısından bu çalışmanın önemli olduğu düşünülmektedir. $\mathrm{Bu}$ gerekçeler doğrultusunda bu araştırmanın amacı, Türkiye'de 2007-2019 yılları arasında (son 12 yılda) yapılan, kavram karikatürlerinin Fen Eğitimi dersi akademik başarısı üzerindeki etkisinin inceleyen deneysel çalışmaların meta-analizini yaparak genel etki büyüklüğunü hesaplamak ve akademik başarının ders türü, yıl ve coğrafi bölgeye göre anlamlı farklılık gösterip göstermediğini belirlemektir. Bu meta-analiz çalışmasında bağımlı değişken akademik başarı iken; moderatör değişkenler kavram karikatürlerinin kullanılma süresi, kullanıldığı çalışmanın türü, çalışmanın yapıldığ1 sınıf düzeyi ve coğrafi bölgedir. Bu amaçla şu sorulara yanıt aranmıştır;

1. Kavram karikatürlerinin Fen Eğitimi dersi akademik başarısı üzerindeki genel etki düzeyi nedir?

2. Kavram karikatürlerinin Fen Eğitimi dersi akademik başarısına etkisi "kavram karikatürü kullanma süresi, araştırmanın türü, sınıf düzeyi ve coğrafi bölge" moderatörlerine göre anlamlı şekilde farklılaşmakta mıdır? 


\section{Kavram Karikatürleri ve Akademik Başarı}

Akademik başarı, öğrenenlerin içeriğe dayalı performansları, bilgi edinme becerileri, sınıflarda düşüncelerini ifade edebilmeleri ve genellikle standart testlerle okuldaki performanslarına ilişkin yeterliklerinin belirlenmesidir (Trow, 2004). Ulusal alan yazında kavram karikatürleri ile akademik başarı arasındaki ilişkiyi inceleyen çalışmalar olduğu görülmüştür (Akbaş ve Toros, 2016; Altunkara, 2013; Balım, Çeliker, Türkoğuz, Evrekli ve Ekici, 2015; Demirel ve Aslan, 2014; Eker ve Karadeniz, 2014; Evrekli ve Balım, 2010; Gölgeli, 2012; Gölgeli ve Saraçoğlu, 2010; Kaplan ve Öztürk, 2015; Köklükaya, Yıldırım ve Selvi, 2016; Özyılmaz-Akamca, Ellez ve Hamurcu, 2009; Say, 2011; Taşlidere, 2013; Teke, Pehlivan ve Haceminoglu, 2013; Tokcan ve Alkan, 2013; Yılmaz, 2013). Bu çalışmalarda akademik başarının artırılmasında kavram karikatürlerinin etkili olduğu belirlenmiştir. Kavram karikatürlerinin akademik başarıya olumlu etkilerinin neler olduğunun tespit edilmesinin ve eğitim ortamında kavram karikatürlerinin nasıl kullanılması gerektiği ile ilgili bilinçli bir tutum benimsemesinin hem alan yazına hem de uygulayıcılara katkı sağlayacağı düşünülmektedir. Ders türü açısından incelendiğinde ulusal alan yazında kavram karikatürlerinin akademik başarı üzerindeki etkisini inceleyen çalışmaların en çok Fen Eğitimi dersinde (Atasoy, Tekbıyık ve Gülay, 2013; Ateş ve Ören, 2018; Ayhan, 2017; Balım, İnel ve Evrekli, 2008; Balım, Çeliker, Türkoğuz, Evrekli ve İnel Ekici, 2015; Baysarı, 2007; Ceylan ve Atabek Yiğit, 2018; Çetin, 2012; Çiçek, 2011; Durmaz, 2007; Evrekli ve Balım, 2015; Gölgeli, 2012; Güngör,2018; Kaptan ve İzgi, 2013; Kara, 2017; Köklükaya; Yıldırım ve Selvi,2016; Meriç, 2014; Ocak, Islak ve Ocak, 2015; Özmen ve diğerleri, 2012; Özüredi, 2009; Özyılmaz-Akamca, 2008; Say ve Özmen, 2018; Sayın, 2015; Sinanoğlu, 2017; Taşkın, 2014; Uzoğlu, Yıldız, Demir ve Büyükkasap, 2013; Yılmaz, 2013; Yolcu, 2013) yürütüldügü görülmektedir. Bu çalışmalarda, kavram karikatürlerinin Fen Eğitimi dersinin kazanımlarına ulaşmak için etkili olduğu ve akademik başarıyı artıırdığı ortaya çıkmıştır. Diğer taraftan alan yazında Fen Eğitimi dersine kavram karikatürü kullanımının öğrencilerin akademik başarılarında anlamlı bir farklılık oluşturmadığı beş çalışmanın olduğu (Ateş ve Ören, 2018; Balım, İnel ve Evrekli, 2008; Göksu, 2012; Kara, 2017; Sayın, 2015) belirlenmiştir. Kavram karikatürlerinin Fen Eğitimi dersi akademik başarısı üzerinde ne düzeyde etkili olduğunun meta-analizle belirlenmesinin alan yazına katkı sağlayacağı düşünülmektedir.

\section{Kavram Karikatürleri ve Kullanılma Süresi}

Bu meta-analiz çalışmasında ilk moderatör analizi kavram karikatürlerinin kullanılma süresidir. Derlenen çalışmalara bakıldığında kavram karikatürlerinin deneysel işlem kapsamında sadece bir hafta kullanıldığı çalışmalar olduğu gibi, 11 haftaya kadar kullanıldığı çalışmalar da bulunmaktadır. Bir değişkenin akademik başarıya etki edebilmesi için gereken süre değişkenlik gösterebileceği için bu çalışmada Fen Eğitimi dersi akademik başarısına etki edebilmesi için kavram karikatürlerinin en iki ay (sekiz hafta) kullanılması gerektiğine alan uzmanları görüşü doğrultusunda karar verilmiştir. Dolayısıyla, moderatör analizi yapılırken çalışmalar iki ay (sekiz hafta) kriterine göre iki gruba ayrılmış, kavram karikatürlerinin kullanılma süresi açısından etki büyüklüklerinde farklılık olup olmadığı kontrol edilmiştir. 
Tablo 1. Kavram Karikatürlerinin Kullanılma Süresi

\begin{tabular}{|c|c|c|}
\hline Çalışma & $\begin{array}{l}\text { Kavram Karikatürlerinin } \\
\text { Kullanılma Süresi }\end{array}$ & $\mathbf{F}$ \\
\hline $\begin{array}{l}\text { Atasoy, Tekbıyık ve Gülay, 2013; Ateş ve Ören, 2018; } \\
\text { Ayhan,2017; Balım vd., 2015; Balım, İnel ve Evrekli, 2008; } \\
\text { Baysarı, 2007; Çetin, 2012; Çiçek, 2011; Durmaz, 2007; } \\
\text { Gölgeli ve Saracoğlu, 2010; Özmen vd., 2012; Güngör, 2018; } \\
\text { Kara, 2017; Özüredi, 2009; Özyılmaz-Akamca, 2008; Sayın, } \\
\text { 2015; Sinanoğlu, 2017; Taşkın, 2014; Yılmaz, } 2013 \text { ve Yolcu, } \\
\text { 2013 }\end{array}$ & 7 hafta ve daha az & 20 \\
\hline $\begin{array}{l}\text { Ceylan ve Atabek Yiğit, 2018, Köklükaya, Yıldırım ve Selvi, } \\
\text { 2016; Say, } 2011\end{array}$ & 8 hafta ve daha fazla & 3 \\
\hline
\end{tabular}

\section{Kavram Karikatürleri ve Araştırma Türü}

Bu meta-analiz çalışmasında ikinci moderatör, kavram karikatürleri üzerinde çalışma yürüten araştırmanın, makale ya da tez olarak yayımlanmasıdır. Ulusal alan yazında kavram karikatürlerinin Fen Eğitimi dersinde akademik başarı üzerindeki etkisini inceleyen çalışmalardan 8'i makale olarak yayınlanırken, 15 'i tez olarak basılmıştır.

Tablo 1. Kavram Karikatürlerinin Yayımlandığı Çalışmanın Türü

\begin{tabular}{llc}
\hline Çalışma & $\begin{array}{l}\text { Araştırmanın } \\
\text { Türüi }\end{array}$ & F \\
\hline $\begin{array}{l}\text { Atasoy, Tekbıyık ve Gülay, 2013; Ateş ve Ören, 2018; Balım ve } \\
\text { diğerleri, 2015; Balı, İnel ve Evrekli, 2008; Ceylan ve Atabek Yiğit, }\end{array}$ & 8 \\
2018; Gölgeli ve Saracoğlu, 2011; Özmen vd., 2012; Köklükaya, & & \\
Y1ldırım ve Selvi, 2016 & & 15 \\
\hline $\begin{array}{l}\text { Ayhan, 2017; Baysarı, 2007; Çetin, 2012; Çiçek, 2011; Durmaz, 2007; Tez } \\
\text { Güngör, 2018; Kara, 2017; Özüredi, 2009; Özyılmaz-Akamca, 2008; }\end{array}$ & \\
$\begin{array}{l}\text { Say, 2011; Sayın, 2015; Sinanoğlu, 2017; Taşkın, 2014; Yılmaz, 2013 } \\
\text { ve Yolcu, 2013 }\end{array}$ & \\
\hline
\end{tabular}

\section{Kavram Karikatürleri ve Sınıf Düzeyi}

Meta-analizi etkileyebilecek üçüncü moderatör, çalışmaların hangi sınıf düzeyinde yapıldığıdır. Fen Eğitimi dersi öğretim programında ilkokul ve ortaokul programında 3. sınıftan itibaren bu ders yer almaktadır. Derlenen çalışmalara bakıldığında en fazla çalışmanın, 7. sınıflarla, sonra sırasıyla 6. sınıflarla, 5. sinıflarla, 8. sinıflarla yapıldığı görülmektedir. Ayrıca, yükseköğretim düzeyinde üniversite öğrencileriyle Fen Eğitimi kapsamında yürütülen iki çalışma bulunmaktadır. 
Tablo 3. Kavram Karikatürlerinin Çalışıldığı Sınıf Düzeyleri

\begin{tabular}{llc}
\hline Çalışma & Sınıf Düzeyi & F \\
\hline Atasoy, Tekbıyık ve Gülay, 2013; Baysarı, 2007; Kara, 2017 & 5. sınıf & 3 \\
\hline $\begin{array}{l}\text { Ayhan, 2017; Balım vd., 2015; Çiçek, 2011; Gölgeli ve Saracoğlu, } \\
\text { 2010; Sinanoğlu, 2017 }\end{array}$ & & 5 \\
\hline $\begin{array}{l}\text { Balım, sınıf İel ve Evrekli, 2008; Ceylan ve Atabek Yiğit, 2018; Çetin, } \\
\text { 2012; Güngör, 2018; Özüredi, 2009; San, 2011; Sayın, 2015, Taşkın, } \\
\text { 2014; Yılmaz, 2013, Yolcu, 2013 }\end{array}$ & \multirow{2}{*}{10} \\
\hline Durmaz, 2007; Özmen vd., 2012; Özyılmaz-Akamca, 2008 & 8. sınıf & 3 \\
\hline Ateş ve Ören, 2018; Köklükaya, Yıldırım ve Selvi, 2016 & Yükseköğretim & 2 \\
\hline
\end{tabular}

\section{Kavram Karikatürleri ve Coğrafi Bölge}

$\mathrm{Bu}$ meta-analiz çalışmasında dördüncü moderatör, araştırmanın yapıldığı coğrafi bölgedir. Ulusal alanyazında kavram karikatürlerinin Fen Eğitimi dersinde akademik başarı üzerindeki etkisini inceleyen çalışmalar incelendiğinde, en çok çalışmanın Ege Bölgesinde yapıldığı, en az çalışmanın ise Doğu Anadolu ve Marmara Bölgesi'nde yapıldığı görülmektedir. Marmara Bölgesi ve Doğu Anadolu Bölgesinde sadece birer adet çalışma yapıldığı için moderatör analizine bu iki bölge dâhil edilmemiştir.

Tablo 2. Kavram Karikatürlerinin Çalışıldığı Coğrafi Bölgeler

\begin{tabular}{llc}
\hline Çalışma & Coğrafi Bölge & F \\
\hline Ateş ve Ören, 2018; Ayhan, 2017; Baysarı, 2007; Balım, İnel ve & Ege Bölgesi & 13 \\
Evrekli, 2008; Balım vd., 2015; Çetin, 2012; Çiçek, 2011; Durmaz, & \\
2007; Özüredi, 2009; Özyılmaz-Akamca, 2008; Sayı, 2015; Taşkı, & \\
2014; Yılmaz, 2013 & Akdeniz Bölgesi & 3 \\
Kara, 2017; Say, 2011 ve Yolcu, 2013 & Karadeniz Bölgesi & 3 \\
Atasoy, Tekbıyık ve Gülay, 2013; Özmen vd., 2012; Sinanoğlu, 2017 & İç Anadolu Bölgesi \\
Ceylan ve Atabek Yiğit, 2018; Gölgeli ve Saracoğlu, 2011 & Marmara Bölgesi & 1 \\
Köklükaya, Yıldırım ve Selvi, 2016 & Doğu \\
Güngör, 2018 & Bölgesi Anadolu & 1 \\
\hline
\end{tabular}

\section{Yöntem}

Belirli bir konu üzerinde ulusal alan yazında yapılan çalışma sayısının son yıllarda hızla artmasından dolayı benzer çalışmaların farklı bulgu ve sonuçlar elde ettiği görülmektedir. $\mathrm{Bu}$ farklılaşma, araştırmacıların o konu alanı ile ilgili tutarlı ve net bir sonuç çıkarmasını zorlaştırmaktadır. Birbirinden bağımsız yapılan çalışmaların analizlerinden yola çıkılarak 
tekrardan bütüncül bir üst/meta-analiz yapılması gerekmektedir. $\mathrm{Bu}$ çalışmada birbirinden bağımsız deneysel çalışmaların sonuçlarını birleştirmek için meta-analiz yöntemi kullanılmıştır. Çalışmada meta-analiz yönteminin tercih edilmesindeki başlıca sebepleri Demir ve Başol (2014) şöyle belirtmektedir;

- Farklılaşan etki büyüklüklerine sahip çalışmalar olması

- Çalışma tasarımlarında metodolojik farklılıklar olması

Esasında meta-analiz, istatistik yardımıyla ortak bir hesaplama birimi belirleyip onun üzerinden çeşitli araştırmaların analiz sonuçlarını karşılaştırmakta ve etki büyüklüklerini belirlemektedir (Rudy, 2001). Benzer şekilde Göçmen (2004), çeşitli araştırmaların analiz sonuçlarının ortak bir metriğe çevrilerek standartlaştırıldığını; bu durum sayesinde etkisi araştırılan yöntem, teknik veya uygulamanın genel etki derecesinin belirlenebildiğini ifade etmektedir. Sonuç olarak, meta-analiz bulguları birleştirmek ve genellenebilir sonuçlara ulaşmak için tekil çalışmalardan elde edilen ve tekil araştırmalara göre daha kapsayıcı olan analiz kümesinin analiz edilmesidir. Card (2012), bir meta-analiz çalışmasının giriş bölümünden sonra alan yazın tarama işlemi, çalışmaları içerme kriterleri, çalışmaların özelliklerini kodlama ve veri analiz stratejisi, çalışmalarla ilgili betimsel bilgiler, heterojenlik testleri ve modelin seçimi, moderatör analizi, tanılayıcı analiz, bulguların gözden geçirilmesi, açıklanması, araştırma önerileri ve sonuç bölümlerinden oluşmasını önermiştir.

\section{Alanyazın Tarama İşlemi}

Kavram karikatürlerinin Fen Eğitimi dersi akademik başarısına etkisini konu alan ulusal çalışmaların tespitinde YÖK Tez Merkezinde (2019) yer alan yayımlanmış ve yayımlanmamış tezler, üniversite kütüphane kataloglarından, Google Akademik’te (2019) yer alan yayımlanmış makalelerden, uluslararası veri tabanlarında yer alan makalelerden ve kongre bildirilerinden yararlanılmıştır. Bu veri tabanlarındaki arama Ekim (2017) ile Ocak (2019) tarihleri arasında yapılmıştır. Bu veri tabanlarında arama yaparken "kavram karikatürleri”, "kavram karikatürleri ve akademik başarı", "kavram karikatürleri ve fen eğitimi", "concept cartoons", "concept image", "concept cartoon and academic success" anahtar kavramları girilmiştir. Toplanan çalışmaların kaynakça kısımları incelenerek ilgili alan yazın araştırılmıştır. Bu işlem sonucunda Türkiye'de yürütülen 62 çalışmaya erişilmişsir. Bu çalışmalardan deneysel veya yarı deneysel yöntemle yürütülmüş olan, Fen Eğitimi dersi kapsamında gerçekleştirilen ve dâhil edilme kriterlerini karşılayan 23 adet tekil araştırma meta-analiz açısından uygun bulunmuştur.

\section{Çalışmaları İçerme ve Dışlama Kriterleri}

Meta-analiz yöntemi kullanılarak yapılan araştırmalarda ilk adım, araştırmaya dâhil edilecek çalışmaların seçim/seçilme ölçütlerinin belirlenmesidir. Abramson (1994) çeşitli çalışmaların sonuçlarının birleştirilmesiyle ilgili dört izlence önermektedir. Öncelikle ilk yapılabilecek adım bilimsel açıdan kalitesiz olan araştırmaların meta-analizden çıkartılmasıdır. İkinci yol ise kalitesiz araştırmalar çıkartılmadan yapılan bulgu sonuçlarını hesapladıktan sonra kalitesiz araştırmaların çıkartılarak ikinci kez analiz yapmaktır. Üçüncü yol ise örneklem sayısı, deneysel desen vb. açıdan kalite farklılığı bulunan araştırmaların bulgularını karşılaştırmaktır. Dördüncü yol ise her bir araştırmaya bilimsel kalitesi ölçüsünde ağırlıklı değer belirleyip analiz yapmaktır. $\mathrm{Bu}$ çalışmada dâhil edilen araştırmaların benzer kalitede olmasına özen gösterilmiştir. $\mathrm{Bu}$ çalışmada yapılacak olan meta-analize dâhil edilme kriterleri şöyle belirlenmiştir: 
- Kavram karikatürlerinin Fen Eğitimi dersinde akademik başarıya olan etkisi ile ilgili deneysel ya da yarı deneysel bir araştırma olması,

- Etki büyüklügünü ortaya çıaracak gerekli istatistiklerin araştırmada rapor edilmesi,

- Araştırma kapsamında üzerinde çalışılan örneklemin Türkiye'den alınması ve hangi bölgeden alındığının belirtilmesi, belirtilmesi,

- Araştırmada ölçülen akademik başarının hangi ders kapsamında yer aldığının

• Araştırmanın örnekleminin öğrenim düzeyinin (ilköğretim, ortaöğretim, yükseköğretim) belirtilmesi,

- Birden fazla başarı testi uygulanmışsa seçkisiz belirlenen herhangi bir testin dâhil edilmesi,

Araştırma kapsamına alınan her çalışmada, çalışma grubunda yer alanların başarı düzeylerinin/erişilerinin, her iki gruba ait son test ölçümlerinin aritmetik ortalamaların, standart sapmaların ve birey sayılarının belirtilmesine, çalışmanın bilimsel araştırma süreci sonunda üretilen bir çalışma olmasına (makale, tez, bildiri gibi) dikkat edilmiştir. Buna göre bu çalışmada yukarıdaki ölçütlere uygun 15 tez ve 8 makale çalışması araştırma kapsamına alınmıştır. Sözü edilen toplam 23 çalışma 2007 - 2019 yılları arasında yayınlanmıştır.

\section{Çalışmaların Kodlanması ve Kodlama Sürecinin Geçerlik ve Güvenirliğinin Sağlanması}

Farklı zamanlarda gerçekleştirilen alan yazın taraması ile dâhil edilme kriterlerine uyan 23 araştırma ile meta-analiz gerçekleştirilmiştir. Bu çalışmaların belirlenmesi ve niteliklerinin ortaya çıkartılması için nesnel ölçütleri olan bir kodlama formu geliştirilmiştir. Demir ve Başol (2014) meta-analizlerde kullanılacak olan kodlama formunun "tüm çalışmaları içerecek kadar genel ancak çalışma farklılıklarını ortaya çıkartacak kadar da özel, açık ve detaylı olması" gerektiğini vurgulamışlardır. Bu meta-analizde geliştirilen kodlama formunda "çalışmanın yayınlandığg yıl, kullanıldığı ders, yapıldığ 1 coğrafi bölge, çalışmanın gerçekleştirildiği sınıf düzeyi, desen türü ve yayın türüne" ilişkin bilgiler yer almaktadır. Ayrıca, meta-analizde etki büyüklüğü hesaplamak için kontrol grubu örneklem sayısı, aritmetik ortalama, standart sapma ile deney grubunun örneklem sayısı, aritmetik ortalama ve standart sapma değerlerine yer verilmiştir. Kansızoğlu ve Cömert (2017), güvenirlik hesabı yapılırken elli ya da daha fazla sayıda çalışma içeren meta-analizlerde yirmi ya da daha fazla çalışmanın güvenirlik hesaplamasına dâhil edilmesi gerektiğini belirtmektedirler. Araştırmacı tarafından yapılan kodlama işlemi bittikten sonra seçkisiz olarak belirlenen 23 adet çalışma ikinci bir değerlendirici tarafından kodlanmış ve kodlamalar üzerinde Miles ve Huberman'ın (1994) uyuşumu 0.86 olarak hesaplanmış ve yeterli bulunmuştur.

\section{Çalışma Karakteristikleri}

Meta-analiz çalışmalarında analize dâhil edilen araştırmaların karakteristikleri, kodlama formuna kaydedilmelidir. Her bir araştırmanın bağımsız değişkenleri o araştırmanın karakteristikleri olarak nitelendirilir. Bu bağımsız değişkenler, etki büyüklüklerini açıklamada oldukça önemli oldukları için detaylı ve açıkça belirtilmelidirler. Bu meta-analiz çalışmasında araştırmacılar tarafindan geliştirilen kodlama formu Tablo 5'te yer almaktadır: 
Tablo 3. Meta-analiz Çalışma Kodlama formu

\begin{tabular}{|c|c|c|c|c|c|c|c|c|c|c|c|c|c|c|c|}
\hline & 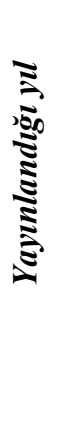 & 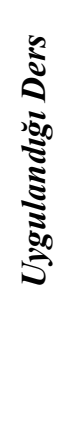 & 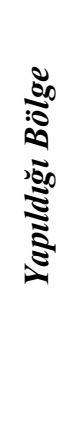 & 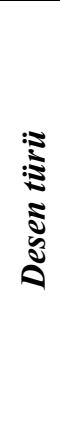 & 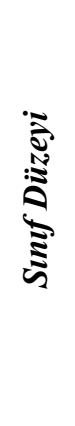 & 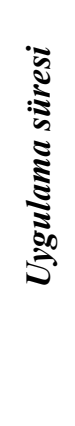 & 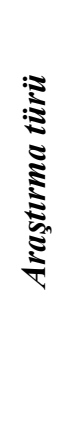 & 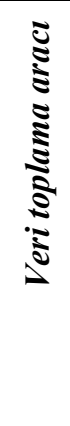 & 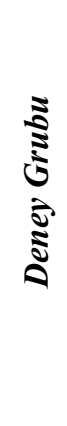 & 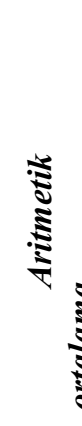 & 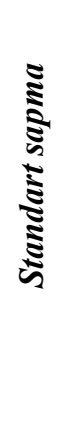 & $\frac{\bar{\Xi}}{\mathfrak{\Xi}}$ & 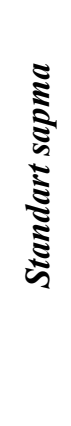 & $t$ & $F$ \\
\hline \multicolumn{16}{|l|}{$\begin{array}{c}\text { Yazar }^{1} \\
\text { Yazar }^{2} \\
\text { vb. }\end{array}$} \\
\hline \multicolumn{16}{|l|}{$\begin{array}{c}\text { Veri } \\
\text { tabanı }\end{array}$} \\
\hline $\begin{array}{c}\text { Anahtar } \\
\text { Kelimele } \\
\text { r }\end{array}$ & & & & & & & & & & & & & & & \\
\hline
\end{tabular}

\section{İstatistiksel Model Seçimi}

Farklı etki büyüklükleri sentezlenirken tercih edilen meta-analiz modeli oldukça önemlidir. Dâhil edilme kriterleri doğrultusunda elde edilen araştırmaların niteliği üzerinde duran heterojenlik testi, kullanılacak modelin karar verilmesine yardımcı olacaktır. Ellis (2010) etki büyüklükleri homojenlik göstermediği durumlarda rastgele etki modelinin tercih edilmesini önermektedirler. Etki modelinin türüne karar verirken Q istatistiği kullanılmaktadır. Anlamlılık değeri kritik değerin altında ve etki büyüklükleri istatistiksel bakımdan anlamlı düzeyde heterojen olan araştırmalarda, heterojen dağılımın olduğu ifade edilebilir (Borenstein, Hedges, Higgins ve Rothstein, 2009; Gavakhan, Moore ve McQay, 2000). Elde edilen ikinci istatistik değeri $\mathrm{I}^{2}$ bu heterojenliğin büyüklüğünü göstermektedir. Bu meta-analiz çalışmasına dâhil edilen araştırmalara ilişkin homojenlik testi Tablo 6'da yer almaktadır:

Tablo 6. Dâhil Edilen Çalışmaların Homojenliğinin Test Edilmesi

\begin{tabular}{lccccc}
\hline Model & $\begin{array}{c}\text { Çalışma } \\
\text { Sayısı }\end{array}$ & $\begin{array}{c}\text { Nokta } \\
\text { Kestirimi }\end{array}$ & $\begin{array}{c}\text { Serbestlik } \\
\text { Derecesi }\end{array}$ & Q Değeri & p \\
\hline SEM & 23 & 0,749 & 22 & 115,037 & .000 \\
REM & 23 & 0,878 & 22 & & \\
\hline
\end{tabular}

Tablo 6 incelendiğinde bu meta-analiz çalışmasında yer alan 23 araştırmanın heterojenlik değerinin anlamlı olduğu $\left(\mathrm{Q}_{(22)}=115,037, \mathrm{p}<.05\right)$ görülmektedir. Mevcut çalışmaların nitelikleri, evren etki büyüklükleri ve değişkenler bakımından farklılık gösterdiği göz önünde bulundurulmuş ve gerçek etki büyüklüğü tahminlenirken ve moderatör analizi yapılırken rasgele etkiler modeli tercih edilmiştir. 


\section{Bulgular}

Bu bölümde meta-analiz çalışmasına dâhil edilen araştırmaların yayın yanlılığı gösterip göstermediği, etki büyüklüklerinin birleştirilmemiş bulguları ve orman grafiği, rasgele etkiler modeline göre birleştirilmiş bulgular ve moderatör analizi ile ilgili bulgular yer almaktadır.

Meta-analiz çalışmalarında yayın yanlılığı teşhis edilmesi gereken önemli bir husustur. Borenstein, Hedges, Higgins ve Rothstein (2009) yayın yanlılığının nedenlerini "geniş etkiler rapor eden çalışmaların daha küçük etkiler rapor eden çalışmalara göre daha kolay yayınlanması, anlamlı olmayan çalışmaların anlamlı çalışmalara göre yayınlanma olasılığının daha az olması, dil yanlılığı (çalışmaların İngilizce veri tabanlarında yer alması, maliyet yanlılığı (veri tabanı seçiminde ücretsiz veya düşük ücretli olanların tercih edilmesi), benzerlik yanlılığı (sadece bir disiplindeki çalışmaları dâhil etmesi) ve tekrar yanlılığı (istatistiksel olarak anlamlı sonuçlar içeren çalışmaların konulara bölünerek yayınlanması)" olarak sınıflandırmaktadır. Borenstein ve diğerlerine (2009) göre yayın yanlılığını belirlemek için en iyi yaklaşım alan yazını olabildiği kadar kapsamlı ele almaktır. Bu meta-analiz çalışmasında derlenen araştırmaların yayın yanlılığı huni grafiği (funnel plot) ile analiz edilmiştir. Cooper, Hedges ve Valentin'e göre (2009) araştırmadaki çalışmalarda eğer yayın yanlılığı olması durumunda, grafikte bir asimetrik görüntü oluşmakta ve grafiğin bir köşesi diğerine göre daha boş kalmaktadır. Örneklem sayısı düşük olan, genel etkisi düşük araştırmaların huninin alt bölümlerinde yer almaktadır. Huninin üst bölümlerinde ise kesinliği/hassasiyeti yüksek araştırmalar yer almaktadır. Yayın yanlılı̆ğıı gösteren grafik Şekil 1'de yer almaktadır:

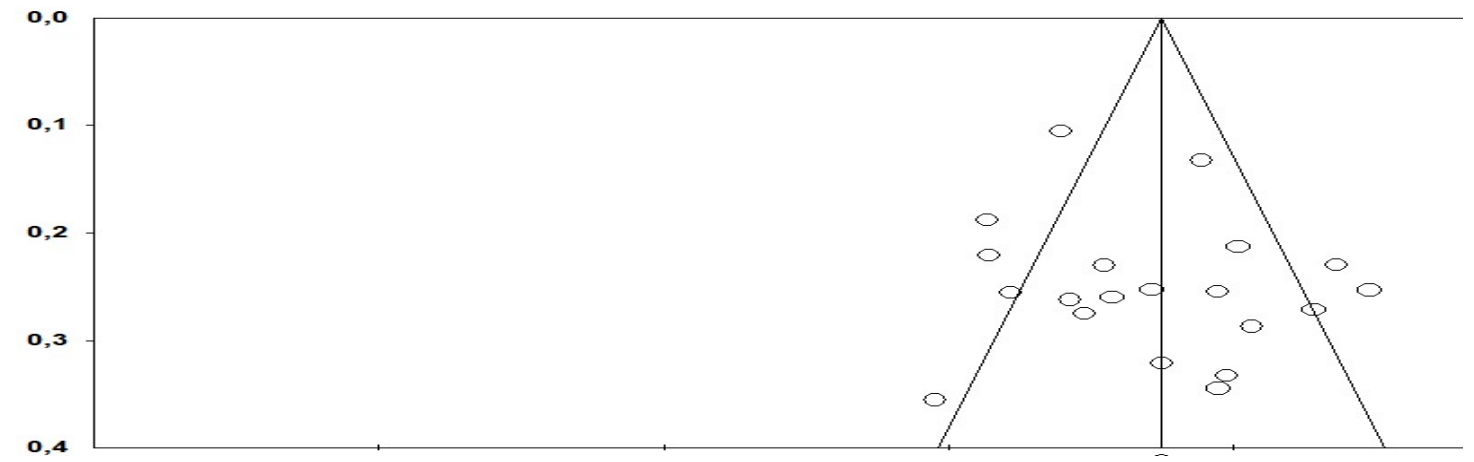

Şekil 1. Yayın yanlılığına ilişkin huni saçılım grafiği

Şekil 1 incelendiğinde bu meta-analiz çalışmasında derlenen araştırmaların çoğunluğunun huni grafiğinin orta ve iç kısmında toplandığı gözlenmektedir. $\mathrm{Bu}$ durum araştırmaların meta-analize olan katkısının orta düzeyde olduğunu göstermektedir. Huni saçılım grafiği incelendiğinde her iki tarafında tam simetrik olmadığı, grafiğin sağ tarafında biriken araştırmaların yayın yanlılığı açısından risk oluşturduğu görülmektedir. Dolayısıyla, ek olarak Duval ve Tweedie'nin Kırp-Yapıştır Kaydırma yöntemi ile çalışmalara ilişkin hesaplanan yanlılık Tablo 7'de yer almaktadır: 
Tablo 7. Duval ve Tweedie'nin Kırp-Yapıştır Kaydırma Yöntemi ile Hesaplanan Yanlılık

\begin{tabular}{lccccc}
\hline & $\begin{array}{l}\text { Kırpılan } \\
\text { çalş̧̧ma }\end{array}$ & $\begin{array}{l}\text { Nokta } \\
\text { Kestirimi }\end{array}$ & $\begin{array}{c}\text { Alt } \\
\text { Düzey }\end{array}$ & Üst Düzey & $\begin{array}{c}\text { Q } \\
\text { değeri }\end{array}$ \\
\hline Gözlenen Değerler & 0 & 0,867 & 0,644 & 1,089 & 114,573 \\
$\begin{array}{l}\text { Düzeltilmiş } \\
\text { Değerler }\end{array}$ & & 0,867 & 0,644 & 1,089 & 114,573 \\
\hline
\end{tabular}

Tablo 7'de simetrinin oluşturulmasında Duval ve Tweeddie'nin "kırp-yapıştır" kaydırma yöntemiyle yapılan düzeltme sonucunda grafiğin bir tarafından diğer tarafa kaydırılması gereken herhangi bir çalışma olmadığı belirlenmiştir. Bu yöntemin kullanılmasıyla elde edilen etki büyüklüğü değeri 0,86723 'tür. Ayrıca, 23 çalışmadan oluşan meta-analizde yayın yanlılığını belirlemek için huni grafiği incelenmiştir. Derlenen araştırmaların çoğunluğunun huni grafiğinin alt bölümlerinde veya dikey çizginin bir kısmında ağırlıklı olarak toplanması, yayın yanlılığına işaret etmektedir (Borenstein ve diğerleri, 2009, s. 284). Ayrıca, yayın yanlılığı incelemede kullanılan diğer yöntem de Orwin'in Güvenli N hesaplamasıdır. Orwin'in Güvenli N yöntemi, bir meta-analiz kapsamında ulaşılamayan, eksik kalmış olabilecek araştırma sayısını belirlemektedir (Borenstein ve diğerleri, 2009, s. 285). Bu yöntem kullanılmış ve bu çalışmada Orwin's Fail-Safe N=1574 olarak hesaplanmıştır. Fail-Safe N hesaplaması sonucunda elde edilen 0,00000 ortalama etki büyüklügünün 0,05000 düzeyine (trivial), yani anlamsız etki düzeyine inmesi için elde edilmesi gereken araştırma sayısı 1574'tür. Bu metaanalizde ortaya çıkan Orwin'in Güvenli N sayısının, elde edilen araştırma sayısından 68 kat fazla olması, yayın yanlılığının olmadığının bir göstergesi olarak kabul edilebilir. Üçüncü olarak yayın yanlılığı için Begg-Mazumdar Kendall's Tau=0,24901, $\mathrm{p}>.05$ olarak belirlenmiş ve yanlılığın olmadığı yönünde kanıt olarak değerlendirilmiştir. Farklı yöntemlerle elde edilen istatistiklere bakıldığında, bu meta-analiz çalışmasının yanlılık açısından güvenilir olduğu ifade edilebilir. Meta-analiz çalışması kapsamında derlenen araştırmaların yüzde 78'inde (18 araştırma) deney grubu lehine anlamlı fark çıkarken; yüzde 22'sinde (5 araştırma) ise gruplar arasında anlamlı bir etki büyüklüğü olmadığı belirlenmiştir.

\section{Meta-analiz Etki Büyüklüğü Sonuçları}

Meta-analiz yoluyla derlenen çalışmaların istatistiksel olarak birleştirilmesi ve tekil çalışmaların etki büyüklüklerinin grup içerisinde dağılımının tutarlı olmasına bağlıdır. Çalışmaların dar güven aralığında olması, ölçmedeki hatanın da düşük olduğunu ve elde edilen bulguların daha güvenilir olduğunu, derlenen çalışmaların da hassasiyetini ve gücünü göstermektedir (Murphy ve Myors, 2004). Şekil 2'de bu meta-analiz kapsamında derlenen çalışmaların ağırlıkları ve etki büyüklükleri yer almaktadır: 


\section{Meta Analiz}

\section{Çalışmalar}

Balim.joel.Evrekli,2008

Ates xe Oren, 2018

Kara, 2017

Baysari, 2007

Balim xe diğerleri,2015

Sayin, 2015

Cicek, 2011

Gölgeli xe Saracoğlu, 2011

Sinanoglu, 2017

Ayhan,2017

Yolcu. 2013

Durmaz,2007

Atasoy, Tekbiyik, Gülay, 2013

ózmen ve diğerleri, ,2012

Taskin, 2014

Gungor, 2018

Koklukava ve diğerleri. 2016

Cetin, 2012

ozvix́lmaz Akamca, 2008

Ozuredi 2009

\section{Şekil 2. Meta-analize ilişkin Hedge's G Değerleri}

Şekil 2 incelendiğinde Balım ve diğerlerine (2015) ait çalışmanın ve Durmaz'a (2007) ait çalışmanın etki büyüklerinin ve güven aralıklarının oldukça yüksek olduğu görülmektedir. Tablo 8 'de ise rasgele etkiler modeli kullanılarak gerçekleştirilen meta-analiz değerleri gösterilmektedir:

Tablo 8. Rasgele Etkiler Modelinde Hesaplanan Meta-analiz Etki Büyüklüğü Sonuçları

\begin{tabular}{lllllll}
\hline $\mathbf{E S}$ & $\mathbf{Z}$ & $\mathbf{Q}$ & $\mathbf{I}^{\mathbf{2}}$ & $\mathbf{S}_{\text {hata }}$ & $\mathbf{E B}_{\text {alt }}$ & $\mathbf{E B}_{\text {ist }}$ \\
\hline 0,867 & 77,642 & $114,573^{*}$ & 80,798 & 0,113 & 0,645 & 1,090 \\
\hline
\end{tabular}

Tablo 8'de görüldüğü üzere ortalama etki büyüklüğünün değeri istatistiksel açıdan anlamlıdır $(Z=77,642, p<.05)$. Ortalama etki büyüklüğü sınıflamasına bakıldığında, Cohen (1988) etki büyüklüğü değerlerini sınıflarken $\mathrm{d} \leq 0,2$ değerleri küçük, $0,2 \leq \mathrm{d} \leq 0,5$ değerleri orta düzey, $d \geq 0,8$ değerleri geniş etki düzeyi olarak sınıflandırmaktadır. Bu çalışmada ortalama etki büyüklügünün pozitif yönde ve Cohen'in (1988) sinıflamasına göre geniş etki büyüklügünde olduğu $(\mathrm{ES}=0,867)$ görülmektedir. Bu sonuç, kavram karikatürleri kullanılan çalışmalarda işlemin etkisinin deney grubu lehine olduğunu ve kavram karikatürleri kullanılarak yapılan öğretimin akademik başarıyı artırmada etkili olduğunu göstermektedir.

\section{Moderatör Analizleri}

Moderatör analizi, sentezlenen etki büyüklüğünü etkileme olasıllı̆̆ bulunan alt gruplar arasındaki ortalama etki büyüklükleri arasındaki farklılıkları belirlemeye yarayan bir yöntemdir (Littel, Corcoran ve Pillai, 2008). Bu meta-analizin amacı kavram karikatürlerinin Fen Eğitimi dersi akademik başarısı üzerindeki etkisini belirledikten sonra, analizin çeşitli moderatörler açısından farklılaşıp farklılaşmadığını belirlemektir. Çalışmanın moderatörleri "kavram karikatürlerinin kullanılma süresi, araştırmanın yapıldığı yıl, sınıf düzeyi ve coğrafi bölge"dir. 
Meta-analiz çalı̧̧malarında genel etki büyüklügünün yönünü ve boyutunu etkileyebilecek değişkenlerin moderatör analizi ile incelenmesi önemlidir. Bu analizin gerçekleştirilmesinde yani alt gruplar arasındaki farklılığın anlamlılığın belirlenmesinde, iki tür Q istatistiğiyle test edilmektedir (Hedges ve Olkin, 1985). Qbetween (Qb) altgruplar arasındaki homojenliği analiz ederken; Qwithin $(\mathrm{Qw})$ grubun kendi içindeki homojenliğini analiz etmektedir (Borenstein, Hedges, Higgins ve Rothstein, 2009). Etki büyüklügünün kavram karikatürlerinin kullanılma süresine göre farklılaşıp farklılaşmadığına ilişkin bulgular Tablo 9'da yer almaktadır:

Tablo 9. Kavram Karikatürlerinin Kullanılma Süresine göre yapılan Moderatör Analizi

\begin{tabular}{|c|c|c|c|c|c|c|c|}
\hline Değişken & $\begin{array}{l}\text { Gruplararası } \\
\text { Homojenlik } \\
\text { Değeri }\end{array}$ & $\mathbf{p}$ & $\mathbf{N}$ & ES & $\mathbf{E S}_{\text {alt }}$ & $\mathbf{E S}_{\text {ust }}$ & $\begin{array}{l}\text { Standart } \\
\text { hata }\end{array}$ \\
\hline Süre & 9,083 & 0,00 & & & & & \\
\hline$>8$ hafta & & & 3 & 1,71 & 0,53 & 0,96 & 0,30 \\
\hline$<8$ hafta & & & 20 & 0,75 & 1,12 & 2,31 & 0,18 \\
\hline
\end{tabular}

Kavram karikatürlerinin kullanılma süreleri kategorik olarak 8 hafta ve daha fazla kullanılan araştırmalar ve 7 hafta ve daha az kullanılan araştırmalar olmak üzere iki gruba ayrılmıştır. Tablo 9'da görüldüğü üzere kavram karikatürlerinin kullanıldığı süreye göre oluşturulmuş gruplar arası homojenlik değeri $\left(\mathrm{Q}_{\mathrm{b}}=9,083 ; \mathrm{p}<.05\right), \mathrm{x}^{2}$ tablosundan $\% 95$ anlamlılık düzeyinde iki serbestlik derecesi ile bulunan kritik değerden büyük bulunmuştur. Dolayısıyla, kavram karikatürlerinin kullanılma süresine göre gruplar arasında 8 hafta ve daha fazla kullanılma süresi lehine anlamlı bir fark bulunmuştur. 8 hafta ve daha fazla kullanılan deneysel işlemlerde kavram karikatürlerinin etki büyüklüğünün $\mathrm{ES}=1,71 ; 7$ hafta ve daha az kullanılan işlemler ise etki büyüklüğünün $\mathrm{ES}=0,75$ olduğu görülmektedir. Kavram karikatürleri ile ilgili çalışmaların etki büyüklüğünün araştırma türü (makale, tez) moderatörüne göre farklılaşıp farklılaşmadığına ilişkin bulgular ise Tablo 10'da yer almaktadır:

Tablo 10. Araştırma Türüne Göre Yapılan Moderatör Analizi

\begin{tabular}{lccccccc}
\hline Değişken & $\begin{array}{l}\text { Gruplararası } \\
\text { Homojenlik Değeri } \\
\left(\mathbf{Q}_{\mathbf{b}}\right)\end{array}$ & $\mathbf{p}$ & $\mathbf{N}$ & $\mathbf{E S}$ & $\mathbf{E S}_{\text {alt }}$ & $\mathbf{E S}_{\text {ist }}$ & $\begin{array}{c}\text { Standart } \\
\text { Hata }\end{array}$ \\
\hline Araştırma & 0,696 & 0,404 & & & & & \\
Makale & & & 8 & 0,738 & 0,366 & 1,111 & 0,190 \\
Tez & & & 15 & 0,935 & 0,663 & 1,206 & 0,138 \\
\hline
\end{tabular}

Tablo 10 incelendiğinde, kavram karikatürlerinin yer aldığı araştırmanın türüne göre oluşturulmuş gruplar arası homojenlik değeri $\left(\mathrm{Q}_{b}=0,696 ; \mathrm{p}>.05\right), \mathrm{x}^{2}$ tablosundan $\% 95$ anlamlılık düzeyinde iki serbestlik derecesi ile bulunan kritik değerden küçük bulunmuştur. Dolayısıyla, kavram karikatürlerinin yer aldığı araştırmanın türüne göre (makale veya tez) gruplar arasında anlamlı bir fark bulunmamıştır. Kavram karikatürlerinin yer aldığı ve makale olarak yayımlanan çalışmaların etki büyüklüğü $\mathrm{ES}=0,738$ iken; tez olarak yayımlanan çalışmaların etki büyüklüğü ise $\mathrm{ES}=0,935$ bulunmuştur. Etki büyüklüğünün kavram karikatürlerinin kullanıldığı sınıf düzeyi moderatörüne göre farklılaşıp farklılaşmadığına ilişkin bulgular Tablo 11'de yer almaktadır: 
Tablo 11. Kavram Karikatürlerinin Kullanıldığı Sınıf Düzeyine Göre Yapılan Moderatör Analizi

\begin{tabular}{|c|c|c|c|c|c|c|c|}
\hline Değişken & $\begin{array}{r}\text { Gruplararası } \\
\text { Homojenlik } \\
\text { Değeri }\left(Q_{b}\right)\end{array}$ & $\mathbf{P}$ & $\mathbf{N}$ & ES & $\mathbf{E S}_{\text {alt }}$ & $\mathbf{E S}_{\text {ist }}$ & $\begin{array}{l}\text { Standart } \\
\text { Hata }\end{array}$ \\
\hline Sinif & 11,068 & 0,026 & & & & & \\
\hline 5.sinif & & & 3 & 0,427 & 0,075 & 0,962 & 0,273 \\
\hline 6.sinif & & & 5 & 0,532 & 0,043 & 0,939 & 0,208 \\
\hline 7.sinif & & & 10 & 1,204 & 0,026 & 1,517 & 0,160 \\
\hline 8.sinif & & & 3 & 1,062 & 0,073 & 1,592 & 0,271 \\
\hline Yükseköğretim & & & 2 & 0,551 & 0,110 & 1,201 & 0,332 \\
\hline
\end{tabular}

Tablo 11'de görüldüğü üzere kavram karikatürlerinin kullanıldığı sınıf düzeyine göre oluşturulmuş gruplar arası homojenlik değeri $\left(\mathrm{Q}_{\mathrm{b}}=11,068 ; \mathrm{p}<.05\right), \chi^{2}$ tablosundan $\% 95$ anlamlılık düzeyinde iki serbestlik derecesi ile bulunan kritik değerden büyük bulunmuştur. Dolayısıyla, kavram karikatürlerinin kullanıldığı sınıflara göre gruplar arasında anlamlı bir fark bulunmuştur. Kavram karikatürlerinin 7.sinıflarda $(\mathrm{ES}=1,204)$ ve 8.sinıflarda $(\mathrm{ES}=1,062)$ uygulandığı araştırmaların etki büyüklüğünün anlamlı olarak diğer çalışmalardan daha yüksek olduğu görülmüsstür. Tablo 7'de en düşük etki büyüklüğünün 5. sınıflarda olduğu $(E S=0,427)$, sonra sirasıyla 6. sinıflarda $(E S=0,532)$ ve yükseköğretimde $(E S=0,551)$ olduğu görülmektedir. Etki büyüklüğünün kavram karikatürlerinin kullanıldığı coğrafi bölge moderatörüne göre farklılaşıp farklılaşmadığına ilişkin bulgular Tablo 12'de yer almaktadır.

Tablo 12. Kavram Karikatürlerinin Kullanıldığı Coğrafi Bölgeye Göre Yapılan Moderatör Analizi

\begin{tabular}{lcllllll}
\hline Değişken & $\begin{array}{l}\text { Gruplararası } \\
\text { Homojenlik } \\
\text { Değeri }\left(\mathbf{Q}_{\mathbf{b}}\right)\end{array}$ & $\mathbf{p}$ & $\mathbf{N}$ & $\mathbf{E S}$ & $\mathbf{E S}_{\text {alt }}$ & $\mathbf{E S}_{\text {ist }}$ & $\begin{array}{l}\text { Standart } \\
\text { Hata }\end{array}$ \\
\hline Coğrafi Bölge & 1,541 & 0,908 & & & & & \\
Akdeniz & & & 3 & 0,890 & 0,204 & 1,57 & 0,350 \\
Doğu Anadolu & & & 1 & 1,016 & $-0,103$ & 2,13 & 0,571 \\
Ege & & & 13 & 0,789 & 0,469 & 1,10 & 0,163 \\
İç Anadolu & & & 2 & 1,317 & 0,482 & 2,15 & 0,426 \\
Karadeniz & & & 3 & 0,816 & 0,135 & 1,49 & 0,348 \\
Marmara & & & 1 & 1,063 & $-0,117$ & 0,24 & 0,602 \\
\hline
\end{tabular}

Tablo 12 incelendiğinde, kavram karikatürü çalışmalarının yapıldığı coğrafi bölgeye göre oluşturulmuş gruplar arası homojenlik değeri $\left(\mathrm{Q}_{\mathrm{b}}=1,541, \mathrm{p}>.05\right), \chi 2$ tablosundan $\% 95$ anlamlılık düzeyinde iki serbestlik derecesi ile bulunan kritik değerden büyük bulunmuştur. Dolayısıyla, kavram karikatürü çalışmalarının gerçekleştirildiği coğrafi bölgeler arasında anlamlı bir fark bulunmamıştır. Tablo 12 'de en düşük etki büyüklüğünün Ege Bölgesi'nde 
gerçekleştirilen çalışmalarda ( $E S=0,789)$, sonra sırasıyla Karadeniz Bölgesi $(E S=0,816)$, Akdeniz Bölgesi $(E S=0,890)$, Doğu Anadolu $(E S=1,016)$, Marmara Bölgesi $(E S=1,063)$ ve en yüksek etki büyüklüğünün İç Anadolu Bölgesi'nde $(E S=1,317)$ gerçekleştirilen çalışmalarda olduğu görülmektedir.

\section{Tartışma ve Sonuç}

$\mathrm{Bu}$ meta-analiz çalışması kapsamında, Fen Eğitimi dersinde kavram karikatürlerinin öğrencilerin akademik başarıları üzerindeki etkisinin incelendiği deneysel çalışmalar bir araya getirilerek genel etki düzeyi belirlenmiştir. Derlenen araştırmalar arasında heterojenlik bulunduğu için etki büyüklüğü rastgele etkiler modeline göre hesaplanmıştır. Etki büyüklüğü değeri yorumlanırken Cohen'in (1988) sınıflaması kullanılmıştır. Cohen (1988) etki büyüklügü değerlerini $\mathrm{d} \leq 0,2$ değerleri küçük, $0,2 \leq \mathrm{d} \leq 0,5$ değerleri orta düzey, $\mathrm{d} \geq 0,8$ değerleri geniş etki düzeyi olarak sınıflandırmaktadır. Araştırma sonuçları genel olarak değerlendirildiğinde, kavram karikatürlerinin Fen Eğitimi dersi akademik başarısına etkisinin pozitif ve geniş düzeyde olduğu görülmektedir. Bu bulguya bakarak kavram karikatürlerinin fen eğitiminde akademik başarıyı artırmada önemli bir araç olduğu görülmektedir. Benzer şekilde, Alkış Küçükaydın (2019) tarafından fen eğitiminde kullanılan kavram karikatürlerinin akademik başarıya etkisi incelenmiştir. 7 adet araştırmanın dâhil edildiği bu meta-analiz çalışmasında fen eğitiminde kullanılan kavram karikatürlerinin öğrencilerin akademik başarısı üzerinde orta düzeyde etkiye sahip olduğu görülmüştür. Bu bulgu, mevcut çalışmanın sonuçlarını destekler nitelikte olup, kavram karikatürlerinin fen eğitimi dersi kapsamında öğrencilerin akademik başarılarını artırabilecek önemli bir değişken olduğunu göstermektedir. Bu meta-analiz çalışmasında moderatör değişken olarak kavram karikatürlerini kullanma süresi, araştırma türü, coğrafi bölge ve sinıf düzeyi belirlenmiştir. Coğrafi bölge ve araştırma türü moderatör değişkenlerine göre çalışmaların etki büyüklükleri arasında farklılık bulunmazken, kavram karikatürlerinin kullanılma süresi ve sınıf düzeyi değişkenlerine göre anlamlı farklılık bulunmuştur. Buna göre kavram karikatürlerinin en az 8 hafta kullanılması gerekmektedir. Ayrıca, kavram karikatürlerinin 7. ve 8. sınıflarda Fen eğitiminde kullanılmasının öğrencilerin akademik başarılarını anlamlı bir şekilde artırdığı, ortak etki büyüklüğünün deney grubu lehine olduğu ve ortalama etki büyüklügünün değerinin pozitif olduğu görülmüştür. Bu nedenle fen öğretim programlarında kavram yanılgılarının sık karşılaşıldığ 1 ünitelerde kavram karikatürlerine yer verilerek öğrencilerin başarıları artırılabilir. Kavram karikatürleri ile ilgili son yıllarda çeşitli araştırmalar yapılsa da bu çalışmaların birleştirilmesi, çalışmaların ortak etki büyüklerinin belirlenmesi için kapsamlı meta-analiz çalışmaları yeterince yapılmamaktadır. Bu durum tekil araştırmaların genellenebilirliğini olumsuz etkilemektedir. Bu yüzden kavram karikatürlerinin Fen eğitimi kapsamında akademik başarıya etkisinin daha iyi yorumlanabilmesi için daha fazla sayıda çalışma yapılmasına ve sonuçlarının sentezlenmesine ihtiyaç vardır. İleriki araştırmalar için kavram karikatürleri ile yaratıcı düşünme, bilimsel epistemolojik inançlar ve eleştirel düşünme gibi ilişkilerin belirlenmesine yönelik meta-analiz çalışmaları yapilabilir. 

Belirlemeye Yönelik Bir Meta-Analiz Çalışması başlıklı çalışmanın yazım sürecinde bilimsel, etik ve alıntı kurallarına uyulmuş; toplanan veriler üzerinde herhangi bir tahrifat yapılmamış, karşılaşılacak tüm etik ihlallerde "Pamukkale Üniversitesi Eğitim Fakültesi Dergisi Yayın Kurulunun" hiçbir sorumluluğunun olmadığı, tüm sorumluluğun Sorumlu Yazara ait olduğu ve bu çalışmanın herhangi başka bir akademik yayın ortamına değerlendirme için gönderilmemiş olduğunu taahhüt ederim. 


\section{Kaynakça}

(* ile işaretlenmiş kaynaklar meta-analizde kullanılmıştır.)

Abramson, J. H. (1994). Making sense of data. New York: Oxford University Press.

Akbaş, Y. ve Toros, S. (2016). Sosyal bilgiler öğretiminde interaktif kavram karikatürleri ve kavram haritaları kullanımının akademik başarıya etkisi. Turkish Studies, 11(9), 53-68.

Alkış Küçükaydın, M. (2019). Fen eğitiminde kullanılan kavram karikatürlerinin akademik başarıya etkisi: meta-analiz çalışması. Inönü Üniversitesi Ĕgitim Fakültesi Dergisi, 20(1), 220-233.

Altunkara, S. (2013). Ekoloji konusunda geliştirilen kavram karikatürlerinin kavramsal anlamaya etkisinin araştırılması. Yayımlanmamış Yüksek Lisans Tezi, Dokuz Eylül Üniversitesi, İzmir.

Arıkurt, E. (2014). Kavram karikatürlerinin ve kavramsal değişim metinlerinin ortaokul 7. Sınıf öğrencilerinin başarılarına, kavramsal değişimlerine ve tutumlarına etkisinin karşılaştırılması. Yayımlanmamış yüksek lisans tezi, Giresun Üniversitesi Fen Bilimleri Enstitüsü, Giresun.

*Atasoy, Ş., Tekbıyık, A., ve Gülay, A. (2013). Beşinci sınıf öğrencilerinin ses kavramını anlamaları üzerine kavram karikatürlerinin etkisi. Journal of Turkish Science Education, 10(1), 176-196.

*Ateş, Ö. ve Ören, F. Ş. (2018). Elektrik konusunu hatırda tutma üzerine kavram karikatürleri ve haritalarının etkisi. Pegem Atıf Indeksi, North America, 355-368.

Atılğanlar, N. (2014). Kavram karikatürlerinin ilköğretim yedinci sınıf ögrencilerinin basit elektrik devreleri konusundaki kavram yanılgıları üzerindeki etkisi. Yayımlanmamış yüksek lisans tezi. Hacettepe Üniversitesi, Ankara.

Aydin, G. (2015). The effects of computer-aided concept cartoons and outdoor science activities on light pollution. International Electronic Journal of Elementary Education, 7(2), 142-156.

*Ayhan, H. (2017). Ortaokul 6. Sinıf kuvvet ve hareket ünitesinde kullanılan kavram karikatürlerinin ögrencilerin akademik başarılarına ve fen öğrenmeye yönelik motivasyonlarına etkisi. Yayımlanmamış Yüksek Lisans Tezi. Gazi Üniversitesi Eğitim Bilimleri Enstitüsü, Ankara.

*Balım, A. G., Çeliker, H. D., Türkoğuz, S., Evrekli, E., ve İnel Ekici, D. (2015). Kavram karikatürleri destekli probleme dayalı öğrenme yönteminin öğrencilerin kavramsal anlama düzeyleri ile problem çözme becerisi algıları üzerine etkisi. Journal of Turkish Science Education, 12(4), 5376.

*Balım, A. G., İnel, D., ve Evrekli, E. (2008). Fen öğretiminde kavram karikatürü kullanımının öğrencilerin akademik başarılarına ve sorgulayıcı öğrenme becerileri algılarına etkisi. İlköğretim Online, 7(1), 188-202.

*Baysarı, E. (2007). Illköğretim düzeyinde 5. sınıf Fen ve Teknoloji dersi canlılar ve hayat ünitesi ögretiminde kavram karikatürü kullanımının öğrenci başarısına, fen tutumuna ve kavram yanılgılarının giderilmesine olan etkisi. Yayımlanmamış Yüksek Lisans Tezi. Dokuz Eylül Üniversitesi Eğitim Bilimleri Enstitüsü, İzmir.

Borenstein, M., Hedges, L.V., Higgins, J. P. T., \& Rothstein, H. R. (2009). Introduction to meta-analysis. Chichester. UK: Wiley.

Card, N. A. (2012). Applied meta-analysis for social science research. New York: The Guilford Press.

*Ceylan, Ö. ve Atabek Yiğit, E. (2018). Analyzing the effect of concept cartoon usage on students' cognitive structures developments and science achievements through flow maps. Science Education International, 29(4), 238-249.

Cohen, J. (1988). Statistical Power analysis for the behavioral sciences. Hillsdale, NJ: Lawrance Earlbaum Associates.

Cooper, H., Hedges, L.V. ve Valentine, J.C. (2009). The handbook of research synthesis and metaanalysis. Russel Sage Foundation, New York.

Çelik, B. ve Gündoğdu, K. (2016). The effect of using humor and concept cartoons in high school ICT lesson on students' achievement, retention, attitude and anxiety. Computers \& Education, 103, 144-157. 
*Çetin, E. (2012). Karikatürler ile zenginleştirilmiş fen ve teknoloji dersinin öğrenci başarısı ve tutumları üzerine etkisi. Yayımlanmamış Doktora Tezi, Selçuk Üniversitesi, Konya.

*Çiçek, T. (2011). Illköğretim 6. sinıf fen ve Teknoloji dersinde Kavram Karikatürlerinin Öğrenci başarısına, tutumuna ve kalıcllĭgına etkisi. Yayımlanmamış yüksek lisans tezi. Celal Bayar Üniversitesi, Manisa.

Dabell, J. (2004). The Maths coordinator's file- using concept cartoons. London: PFP Publishing.

Demir, Y. (2008). Kavram yanılgllarının belirlenmesinde kavram karikatürlerinin kullanılması. Yayımlanmamış yüksek lisans tezi, Atatürk Üniversitesi Fen Bilimleri Enstitüsü, Erzurum.

Demir, S. ve Başol, G. (2014). Bilgisayar destekli matematik öğretiminin (BDMÖ) akademik başarıya etkisi: Bir metaanaliz çalışması. Educational Sciences: Theory \& Practice, 14, 2013-2035.

Demirel, R. ve Aslan, O. (2014). Kavram karikatürleriyle desteklenen fen ve teknoloji öğretiminin öğrencilerin akademik başarıları ve kavramsal anlamalarına etkisi. Eğitimde Kuram ve Uygulama, 10(2), 368-392.

*Durmaz, B. (2007). Yapılandırıcı fen ögrretiminde kavram karikatürlerinin öğrencilerin başarısı ve duyuşsal özelliklerine etkisi (Muğla ili merkez ilçe örneği). Yayımlanmamış yüksek lisans tezi, Muğla Üniversitesi Fen Bilimleri Enstitüsü, Muğla.

Eker, C. ve Karadeniz, O. (2014). The effects of educational practice with cartoons on learning outcomes. International Journal of Humanities and Social Science, 4(14), 223-234.

Ellis, P. D. (2010). The essential guide to effect sizes: Statistical power, meta-analysis, and the interpretation of research results. Cambridge: Cambridge University Press.

Erdoğan, A. ve Özsevgeç, L. C. (2012). Kavram karikatürlerinin öğrencilerin kavram yanılgılarının giderilmesi üzerindeki etkisi: Sera etkisi ve küresel 1sınma örneği. Turkish Journal of Education, 1(2), 1-13.

Evrekli, E. ve Balım, A. G. (2010). Fen ve teknoloji öğretiminde zihin haritası ve kavram karikatürü kullanımının öğrencilerin akademik başarılarına ve sorgulayıcı öğrenme becerileri algılarına etkisi. Batı Anadolu Eğitim Bilimleri Dergisi, 1(2), 76-98.

Evrekli, E. ve Balım, A. G. (2015). Fen derslerinde animasyon destekli kavram karikatürleri kullanımının altıncı sınıf öğrencilerinin sorgulayıcı öğrenme becerileri algılarına etkisi. Batı Anadolu Ĕğitim Bilimleri Dergisi, 6(11), 109-136.

Gavakhan, D. J., Moore, A. R., \& McQay, H. J. (2000). An evaluation of homogeneity tests in metaanalysis in pain using simulations of patient data. Pain, 85, 415-424.

Göçmen, G. (2004). Meta-analizin genel bir değerlendirmesi. Sakarya Üniversitesi Eğitim Fakültesi Dergisi, 7, 186-192.

Göksu, H. K. (2012). Fen ve teknoloji ögrretiminde kavram karikatürlerinin öğrencilerin akademik başarılarına ve tutumlarına etkisi. Yayımlanmamış Yüksek Lisans Tezi, Mehmet Akif Ersoy Üniversitesi, Burdur.

Gölgeli, D. (2012). Düşün-eşleş-paylaş tekniği ile birlikte kullanılan kavram karikatürlerinin öğrencilerin akademik başarisl ile fen ve teknoloji dersine olan tutumlarina etkisinin incelenmesi. Yayınlanmamış yüksek lisans tezi, Erciyes Üniversitesi Eğitim Bilimleri Enstitüsü, Erciyes.

*Gölgeli, D. ve Saraçoğlu, S. (2010). Fen ve teknoloji dersi 'işık ve ses' ünitesinin öğretiminde kavram karikatürlerinin kullanımının öğrencilerin akademik başarısına etkisi. Sosyal Bilimler Enstitüsü Dergisi, 2(31), 113-124.

Gül, Ş., Köse, E. Ö., ve Konu, M. (2014). Genetik ünitesinin öğretiminde kavram karikatürü kullanımının biyoloji öğretmeni adayları üzerine etkisi. Fen Bilimleri Öğretimi Dergisi, 2(1), 1-22.

Güler, H. K., Çakmak, D., ve Kavak, N. (2013). Karikatürlerle yapılan matematik öğretiminin öğrencilerin akademik başarılarına ve tutumlarına etkisi. Eğitim Fakültesi Dergisi, 26 (1), 149160. 
*Güngör, H. (2018). Fen ve teknoloji ögretiminde kavram karikatürü kullanımının ilköğretim 7. sınıf ögrencilerin akademik başarılarına etkisi. Yayımlanmamış Yüksek Lisans Tezi, Necmettin Erbakan Üniversitesi Eğitim Bilimleri Enstitüsü, Konya.

Gürol M. (2003). Aktif öğrenmeyi temel alan oluşturmacı öğrenme tasarımının uygulanması ve başarıya etkisi. Manas Üniversitesi Sosyal Bilimler Dergisi, 7, 169- 179.

Hedges L.V., \& Olkin I. (1985). Statistical methods for metaanalysis. Boston, Mass: Academic Press.

İnel, D., Balım, A. G., ve Evrekli, E. (2009). Fen öğretiminde kavram karikatürü kullanımına ilişkin öğrenci görüşleri. Necatibey Eğitim Fakültesi Elektronik Fen ve Matematik Eğitimi Dergisi, 3(1), 1-16.

Kabapınar, F. (2005). Yapılandırmacı öğrenme sürecine katkıları açısından fen derslerinde kullanılabilecek bir öğretim yöntemi olarak kavram karikatürleri. Kuram ve Uygulamada Ĕ̆itim Bilimleri, 5(1), 101-146.

Kansızoğlu, H. B. ve Cömert, Ö. B. (2017). The effect of the process approach on students' writing success: A meta-analysis. Çukurova Üniversitesi Eğitim Fakültesi Dergisi, 46(2), 541-586.

Kaplan, A. ve Öztürk, M. (2015). The effect of concept cartoons to academic achievement in instruction on the topics of divisibility. Mathematics Education, 10(2), 67-76.

Kaptan, F. ve İzgi, Ü. (2014). The effects of use concept cartoons attitudes of first grade elementary students towards science and technology course. Procedia Social and Behavioral Sciences, 116, 2307-2311.

*Kara, M. (2017). İlköğretim 5.sınıf yer kabuğunun gizemi ünitesinde kavram karikatürü kullanımının ögrenci başarısına etkisi. Yayımlanmamış Yüksek Lisans Tezi, Akdeniz Üniversitesi Eğitim Bilimleri Ensitüsü, Antalya.

Keogh, B., Naylor, S., \& Wilson, K. (1998). Concept cartoons: A new perspective on physics education. Physics Education, 33(4), 219-224.

Kirisçioğlu, S. ve Başdaş, E. (2007). Yapılandırmacı öğrenme ortamlarında fen ve teknoloji derslerinde kullanılabilecek kavram karikatürleri ve etkinlik örnekleri. Eğitimde Yeni Yönelimler IV: Yapılandırmacılık ve Ögrretmen, Ankara: Özel Tevfik Fikret Okulları.

*Köklükaya, A. N, Yıldırım, E., ve Selvi, M. (2016). The effects of cartoons prepared by pre-service science teachers on academic achievement and anxiety level. Journal of Theory and Practice in Education, 12(2), 427-446.

Littell, J. H., Corcoran, J., \& Pillai, V. (2008). Systematic reviews and meta-analysis. New York, NY: Oxford University Press.

Long, S., \& Marson, K. (2003). Concept Cartoons. Hands on Science, 19(3), 22-23.

Martinez, Y. M. (2004). Does the $k$-w-l reading strategy enhance student understanding in honors high school science classroom? Unpublished masters thesis, Fullerton: California State University.

Meriç, G. (2014). Fen ve teknoloji dersinde kavram karikatürlerinin öğrencilerin kavramsal anlama, motivasyon ve tutum düzeyleri üzerine etkisi. Yayımlanmamış yüksek lisans tezi, Celal Bayar Üniversitesi Fen Bilimleri Enstitüsü, Manisa.

Miles, M. B., \& Huberman, A. M. (1994). Qualitative data analysis ( $2^{\text {nd }}$ ed.). Thousand Oaks, CA: Sage.

Murphy, K.R., \& Myors, B. (2004). Statistical power analysis: A simple and general model for traditional and modern hypothesis tests. Mahwah, NJ: Erlbaum

Naylor, S., Downing, B., \& Keogh, B (2001). An empirical study of argumentation in primary science, using concept cartoons as the stimulus. Paper presented at $3^{\text {rd }}$ European Science Education Research Association Conference, Thessaloniki, Greece.

Ocak, I., Islak, F. G., ve Ocak, G. (2015). İlkokul 4. sınıf fen bilimleri dersinde kavram karikatürü kullanımının akademik başarıya etkisi. Bartın Üniversitesi Eğitim Fakültesi Dergisi, 1, 119-132.

Oruç, S., \& Teymuroglu, B. (2011). The effects of using cartoon in teaching social sciences on attitudes of students against to social science course. Procedia-Social and Behavioral Sciences, 15, 3211 3215 . 
*Özmen, H., Demircioğlu, G., Burhan, Y., Naseriazar, A., ve Demircioğlu, H. (2012). Using laboratory activities enhanced with concept cartoons to support progression in students' understanding of acid-base concepts. Asia-Pasific Forum on Science Learning and Teaching, 13(1), 1-29.

*Özüredi, Ö. (2009). Kavram karikatürlerinin ilköğretim 7. sinlf fen ve teknoloji dersi, insan ve çevre ünitesinde yer alan "besin zinciri" konusunda öğrenci başarısı üzerindeki etkisi. Yayımlanmamış yüksek lisans tezi, Celal Bayar Üniversitesi Fen Bilimleri Enstitüsü, Manisa.

*Özyılmaz-Akamca, G. (2008). İlköğretimde analojiler, kavram karikatürleri ve tahmin-gözlem açıklama teknikleriyle desteklenmiş fen ve teknoloji eğitiminin öğrenme ürünlerine etkisi. Yayımlanmamış Doktora Tezi, Dokuz Eylül Üniversitesi Eğitim Bilimleri Enstitüsü, İzmir.

Özyılmaz-Akamca, G., Ellez, A. M., ve Hamurcu, G. (2009). Effects of computer aided concept cartoons on learning outcomes. Procedia Social and Behavioral Sciences, 1, 296-301.

Rudy, A. C. (2001). A meta-analysis of the treatment of anorexia nervosa: A proposal. New York: Ithaca College.

Saka, A., Akdeniz, A. R., Bayrak, R., ve Asilsoy, Ö. (2006). Canlılarda enerji dönüşümü” ünitesinde karşılaşlan yanılgıların giderilmesinde kavram karikatürlerinin etkisi. VII. Ulusal Fen Bilimleri ve Matematik Ĕgitimi Kongresi, Ankara.

*Say, S. (2011). Kavram karikatürlerinin 7. sinı ögrencilerinin maddenin yapısı ve özellikleri konusunu ögrenmelerine etkisi. Yayımlanmamış Yüksek Lisans Tezi, Karadeniz Teknik Üniversitesi Eğitim Bilimleri Enstitüsü, Trabzon.

Say, F. ve Özmen, H. (2018). Effectiveness of concept cartoons on $7^{\text {th }}$ grade students' understanding of "the Structure and Properties of Matter". Türk Fen Eğitim Dergisi, 15(1),.1-24

*Sayın, Ş. (2015). Illköğretim fen ve teknoloji dersi 7. sinlf ışılk ünitesinin ögrretiminde kavram karikatürleri kullanımının ögrencilerin akademik başarıları, sorgulayıcı öğrenme becerileri, algıları ve motivasyonları üzerine etkisi. Yayımlanmamış yüksek lisans tezi, Celal Bayar Üniversitesi, Manisa.

*Sinanoğlu, K. (2017). Kavram karikatürleri ve kavramsal değişim metinlerinin 6. sinıf öğrencilerinin bilişsel yüküne, akademik başarısına ve kalıcılı̆̆ına etkisi. Yayımlanmamış Yüksek Lisan Tezi, Ordu Üniversitesi Fen Bilimleri Enstitüsü, Ordu.

Şaşmaz-Ören, F. (2009). Öğretmen adaylarının kavram karikatürü oluşturma becerilerinin dereceli puanlama anahtarıyla değerlendirilmesi. E-Journal of New World Sciences Academy, 4(3), 9941016.

*Taşkın, Ö. (2014). Fen ve teknoloji ögretiminde kavram karikatürü kullanımının öğrenci başarısı ve tutumuna etkisi. Yayınlanmamış yüksek lisans tezi, Celal Bayar Üniversitesi Fen Bilimleri Enstitüsü

Taşlıdere, E. (2013). Kavram karikatürleri ile zenginleştirilmiş çalışma yapraklarının öğrencilerin geometrik optik konusundaki kavramsal anlamalarına etkisi. Ĕgitim ve Bilim, 38 (167). 145-161.

Teke, E., Pehlivan, M., ve Haceminoglu, E. (2013) The effect of the science and technology course integrated with cartoonss on students achievement and attitudes. Journal of Educational and Instructional Studies, 3(2) 129- 134.

Tokcan, H. ve Alkan, G. (2013). Sosyal bilgiler öğretiminde kavram karikatürlerinin öğrenci başarısına etkisi. Ahi Evran Üniversitesi Kirş̧ehir Eğitim Fakültesi Dergisi, 14(2), 1-19.

Trow, (2004). Academic achievement, In S. Dandapani (ed.) A Text book of advanced educational psychology (pp. 434-439). New Delhi: Atlantic Publishers.

Uzoğlu, M., Yıldız, A., Demir, Y., ve Büyükkasap, E. (2013). Fen bilgisi öğretmen adaylarının ışıkla ilgili kavram yanılgılarının belirlenmesinde kavram karikatürlerinin ve açık uçlu soruların etkililiklerinin karşılaştırılması. Ahi Evran Üniversitesi Kırşehir Eğitim Fakültesi Dergisi, 14(1), 367-388. 
Webb, P., Williams, Y., \& Meiring, L. (2008). Concept cartoons and writing frames: Developing argumentation in South African science classrooms?. African Journal of Research in SMT Education, 12(1), 4-17.

*Yılmaz, T. (2013). Kavram karikatürleriyle desteklenmiş bilimsel hikayelerin öğrencilerin akademik başarıları, tutumlarl ve motivasyonları üzerine etkisi. Yayımlanmamış yüksek lisans tezi, Celal Bayar Üniversitesi, Manisa.

*Yolcu, H. (2013). Fen öğretiminde kavram karikatürleri tekniğinin yapılandırmacı ögrrenme ortamında kullanılmasının ilköğretim 7. sınıf ögrencilerinin başarı, tutum ve mantıksal düşünme yeteneklerine etkisi. Yayımlanmamış yüksek lisans tezi, Mustafa Kemal Üniversitesi Sosyal Bilimler Enstitüsü, Hatay. 


\section{Extended Abstract}

\section{Introduction}

With the increase of individuality and freedom in education in the $21^{\text {st }}$ century, students can associate what they learn during their learning process with their experiences and make learning permanent. Concept cartoons are one of the visual tools that will enable the students' active participation in this process (Balım, İnel and Evrekli, 2008). Concept cartoons are caricature drawings prepared to encourage questioning which creates a discussion environment and produces scientific thinking (Long and Marson, 2003). According to Dabell (2004), concept cartoons are cognitive drawings in which speeches are presented to the learner in a cartoonized manner. The characters used in concept cartoons represent different perspectives on the subject (Naylor, Downing and Keogh, 2001). When the studies on concept cartoons in the literature are reviewed, it is seen that concept cartoons increase students' interest towards the course (Kaptan and İzgi, 2014), help their developmental process in many ways (İnel, Balım, Evrekli, 2009), lead to better understanding what they learn in lessons (Taşlıdere, 2013), develop their learning skills (Evrekli, Balım, 2010), enhance conceptual understanding and problem-solving skills (Balım, Çeliker, Türkoğuz, Evrekli, and Ekici, 2015), reduce misconceptions, prevent new misconceptions and enable students to understand the course subjects better (Demirel and Aslan, 2014; Atılğanlar, 2014), positively affect students' academic achievement (Akbaş and Toros, 2016; Köklükaya, Yıldırım and Selvi, 2016; Yılmaz, 2013; Çelik and Gündoğdu, 2016; Kaplan and Öztürk, 2015).

This research aims to perform a meta-analysis of the studies -conducted between 20072019 (in the last 12 years) in Turkey- which examine the effect of the concept cartoons on students' academic achievement in science course. Also, it aims to determine whether concept cartoons' effect differ significantly according to the duration of their use, course type, study year, and geographical region.

\section{Method}

In order to determine concept cartoons's effect on the achievement in science course, metaanalysis is used as research method to perform a holistic analysis combining the studies conducted independently of each other. Among all studies obtained, only 23 individual studies have been found suitable for the meta-analysis which are conducted with an experimental or semi-experimental method, performed in the science course, and meeting the inclusion criteria. Since there is heterogeneity among the studies, the effect size has been calculated by random effects model.

\section{Findings and Discussion}

In order to combine all studies statistically which are gathered through meta-analysis, there is a need for coherent distribution of individual studies' effect sizes within group. The fact that the studies are within the narrow confidence interval shows that the error in measurement is low and the results are more reliable (Murphy and Myors, 2004). The weights and effect sizes of the studies -which are compiled as part of this meta-analysis- are calculated and it is seen that the effect sizes and confidence intervals of the studies by Balım et al. (2015) and Durmaz (2007) are quite high. Then the random effects model has been used to calculate average effect size of overall studies. Consequently, this meta-analysis related to concept cartoons reveals that the 
average effect size value is statistically significant $(Z=7.642, p<.05)$. It is observed that the average effect size is found to be 0.867 and it is in positive way. This result shows that the effect of the concept cartoons is in favor of the experimental group and that concept cartoonsbased instruction is effective in terms of increasing the academic achievement.

As a result of the correction made by Duval and Tweeddie's "trim and fill" method, it appears that there is no study to be shifted from one side of the graph to the other. The effect size value obtained by this method is 0.86723 . Also, there are other methods used to examine publication bias. One of these methods is Orwin's Fail-Safe N calculation, which determines the number of the studies to be reached in order to make the result insignificant as part of a metaanalysis (Borenstein et al., 2009, p. 285). Orwin's Fail-Safe N value is found as 1574 by this method. It is 1574 which is the number of the studies that should be obtained in order to reduce the average effect size of 0.00 , to 0.05 level, which is the insignificant effect level. The fact that Orwin's Fail-Safe N number in this meta-analysis was 68 times higher than the number of studies obtained can be accepted as an indicator that there is no publication bias. Taking into consideration the statistics obtained by different methods, it can be seen that this meta-analysis is reliable in terms of bias. In $78 \%$ of the studies (18 studies), there is a significant difference in favor of the experimental group. Then, the moderator analyses are performed.

\section{Conclusion}

This meta-analysis aims to identify the overall effect size of experimental studies examining the effect of concept cartoons on students' academic achievement in science course. Cohen's (1988) classification is used for interpreting the effect size values. According to Cohen's (1988) classification, $d \leq 0,2$ means small effect, $0.2 \leq \mathrm{d} \leq 0.5$ is moderate effect, and $\mathrm{d} \geq 0.8$ is large effect. According to this classification, concept cartoons have large effect on academic achievement in science course $\left(\mathrm{I}^{2}=0.867\right)$ revealing that concept cartoons are highly effective in teaching contents in science course. In this meta-analysis, significant differences are only found depending on two moderators which include the duration of using concept cartoons and class level. Accordingly, it comes out that concept cartoons increase academic achievement in science course when they are applied for 8 weeks and more, and in the $7^{\text {th }}$ and $8^{\text {th }}$ grades. When the results of the study are evaluated in general, there is a positive and large effect size of all studies which analyse the effect of concept cartoons on the academic achievement in science courses. It might be an indicator that utilizing concept cartoons can increase students' achievements in other disciplines, as well. Literature review shows that there have been various studies on concept cartoons' effect on academic achievemen in recent years. However, a sufficient comprehensive meta-analysis is not conducted to combine these studies and determine their common effect sizes. This situation negatively affects the generalizability of individual studies. Therefore, there is need for more studies to make a better interpretation of concept cartoons' effect on the academic achievement in science course. In further studies, meta-analyses can be conducted to identify the relationship between concept cartoons and creative thinking and critical thinking. 